\title{
无外加溶剂条件下二甲氨基硫代甲酰氯对亚砜的脱氧还原
}

\author{
王兴越 $a, b$ 许昌林 $a$ 关宏宇*, $a$ 林 受 $a$ 黄 鹏*,a \\ ( ${ }^{a}$ 辽宁大学化学院 沈阳 110036) \\ $(b$ 中国石油化工股份有限公司 大连(抚顺)石油化工研究院 辽宁大连 116045)
}

\begin{abstract}
摘要 报道一种简便高效地将亚砜脱氧还原的方法. 在 $100{ }^{\circ} \mathrm{C}$ 条件下, 无需外加溶剂, 一系列脂肪和芳香亚砜可与二 甲氨基硫代甲酰氯反应，以中等到优异的产率生成相应的产物硫醚. 该反应可以兼容多种官能团，并且适合克级规模 合成. 反应可能经过硫代亚砜中间体的生成和分解成硫醚和硫单质的过程.

关键词 亚砜; 硫醚; 脱氧; 还原; 硫代
\end{abstract}

\section{Deoxygenation of Sulfoxides with Dimethylthiocarbamoyl Chloride in the Absence of Additional Solvent}

\author{
Wang, Xingyue $\mathrm{e}^{a, b} \quad \mathrm{Xu}$, Changlin ${ }^{a} \quad$ Guan, Hongyu ${ }^{*, a} \quad$ Lin, $\mathrm{Mi}^{a} \quad$ Huang, Peng ${ }^{*, a}$ \\ ( ${ }^{a}$ College of Chemistry, Liaoning University, Shenyang 110036) \\ ( ${ }^{b}$ Dalian (Fushun) Research Institute of Petroleum and Petrochemicals, China Petroleum \& Chemical Corporation, \\ Liaoning, Dalian 116045)
}

\begin{abstract}
A simple and effective method of sulfoxide deoxidation is reported. Without any additional solvent, a series of aliphatic and aromatic sulfoxides could react with dimethylthiocarbamoyl chloride at $100{ }^{\circ} \mathrm{C}$ to afford the corresponding thioethers in moderate to excellent yields. This reaction is compatible with a number of functional groups and is suitable for gram-scale synthesis. A mechanism involving the formation of a thiosulfoxide intermediate and its degradation to thioether and elemental sulfur is proposed for the reaction.
\end{abstract}

Keywords sulfoxide; thioether; deoxygenation; reduction; thionation

\section{Introduction}

The deoxygenation of sulfoxides to the corresponding thioethers is an important reaction due to its considerable application in chemical and biochemical synthesis..$^{[1]}$ Over the past decades, a broad range of reagents, like various low-valent metallic species [e.g., $\mathrm{NbCl}_{5} / \mathrm{Zn}, \mathrm{HfCl}_{4} / \mathrm{Zn}$, $\left.\mathrm{WCl}_{6} / n-\mathrm{BuLi}\right]{ }^{[2]}$ metal hydride reagents $\left[\right.$ e.g., $\mathrm{CoCl}_{2}$ • $6 \mathrm{H}_{2} \mathrm{O} / \mathrm{NaBH}_{4}$, diisobutylaluminum hydride (DIBAH), $\left.\mathrm{LiAlH}_{4}\right],{ }^{[3]}$ metal powder [e.g., $\left.\mathrm{Fe}, \mathrm{Mg}\right],{ }^{[4]}$ phosphorus-containing compounds [e.g., $\left.\mathrm{PCl}_{3}, \mathrm{P}_{2} \mathrm{I}_{4}, \mathrm{ClP}(\mathrm{OEt})_{2}\right],{ }^{[5]}$ thionating reagents [e.g., Lawesson's reagent, $\mathrm{P}_{4} \mathrm{~S}_{10}$, $\left.\mathrm{PSBr}_{3}\right]{ }_{,}^{[6]}$ halide ions [e.g., $\mathrm{Tf}_{2} \mathrm{O} / \mathrm{KI}$, ascorbic acid/NBS, benzyl DABCO bromide] ${ }^{[7]}$ hydrogen, ${ }^{[8]}$ boranes [e.g., $\mathrm{B}_{2} \mathrm{cat}_{2}, \mathrm{Me}_{2} \mathrm{BBr}, \mathrm{BH}_{3} / \mathrm{MoO}_{2} \mathrm{Cl}_{2}$ ], ${ }^{[9]}$ silanes [e.g., $\mathrm{Si}_{2} \mathrm{Me}_{6}$, $\left.\mathrm{HReO}_{4} / \mathrm{PhSiH}_{3}, \mathrm{~B}\left(\mathrm{C}_{6} \mathrm{~F}_{5}\right)_{3} / \mathrm{PhSiH}_{3}\right],{ }^{[10]}$ and sulfinyl chlorides [e.g., $\left.\mathrm{CF}_{3} \mathrm{SOCl}, \mathrm{CH}_{3} \mathrm{SOCl}\right]^{[11]}$ have been utilized to effect such transformation. However, most of the protocols suf- fered from the use of contaminative and/or smelly reagents, functional group incompatibility, harsh reaction conditions, and difficult workup procedures. Moreover, these deoxygenation reactions are always performed in hazardous organic solvents, of which the dryness and purity affected the yields of thioethers dramatically, and only limited examples of deoxygenation were reported under solvent-free conditions. Therefore, it is worthwhile to develop a facile approach for the deoxygenation of sulfoxides with readily available reagents under metal-free as well as solvent-free conditions.

On the other hand, dimethylthiocarbamoyl chloride (DMTCC) is generally used as a cost effective and commercially available thiocarbamoylating agent to react with $\mathrm{C}-, \mathrm{N}-, \mathrm{O}-$, and S-centered nucleophiles, with the formation of thioamides, ${ }^{[12]}$ thioureas, ${ }^{[13]}$ carbamothioates, ${ }^{[14]}$ and carbamodithioates. ${ }^{[15]}$ DMTCC also serves as a sulfur

* Corresponding authors. E-mail: guanhongyu@lnu.edu.cn; huangp019@126.com

Received February 1, 2021; revised April 16, 2021; published online May 13, 2021.

Project supported by the Scientific Research Funds of Liaoning Education Department (No. LYB201606).

辽宁省教育厅科学研究基金(No. LYB201606)资助项目. 
source in Newman-Kwart rearrangement, which permits the straightforward preparation of thiophenols from the corresponding phenols via a thermal $O$-aryl to $S$-aryl rearrangement of aromatic carbamothioates. ${ }^{[16]}$ Nonetheless, the applications of DMTCC in other reactions, rather than thiocarbamoylation and Newman-Kwart rearrangement, were rarely studied. Inspired by the Newman-Kwart rearrangement and continuing our research interest in sulfur chemistry, ${ }^{[17]}$ we envisioned that DMTCC may be used as a thionating reagent to reduce sulfoxides under appropriate conditions. From the operational perspective, the use of DMTCC as a thionating reagent would be more advantageous than Lawesson's reagent or $\mathrm{P}_{4} \mathrm{~S}_{10}$, as DMTCC is odorless and exists as stable crystalline materials at room temperature that can be conveniently and safely handled in typical laboratory operations. Thus, the reactions of sulfoxides with DMTCC were investigated. As a result of these studies, we developed a facile and efficient method for the deoxygenation of sulfoxides in the absence of any additional solvent. It should be mentioned that, in comparison to reactions in large amount of solvents, reactions without additional solvents can significantly save costs, decrease energy consumption, reduce the reactor size and capital investment. ${ }^{[18]}$ Herein, we wish to report our experimental results and a proposed mechanism involved in the deoxygenation reaction.

\section{Results and discussion}

Our study began with the reaction of diphenyl sulfoxide (1a) with DMTCC. Since DMTCC is a low-melting-point solid compound (m.p. 39 43 ${ }^{\circ} \mathrm{C}$ ) and is stable at elevated temperatures $\left(<150{ }^{\circ} \mathrm{C}\right)$, its reaction with 1 a was directly performed under thermal conditions without any additional catalyst and solvent. When 1a was treated with 1.0 equiv. of DMTCC at $100{ }^{\circ} \mathrm{C}$ for $2 \mathrm{~h}$, the desired diphenyl thioether (2a) was produced and isolated in $81 \%$ yield along with a small amount of intact substrate 1a. This result encouraged us to optimize the reaction conditions, including reaction temperature and the loading amount of DMTCC. As shown in Table 1, lowering the temperature to $80{ }^{\circ} \mathrm{C}$ led to a significant decrease in the yield of $\mathbf{2 a}$, while the reaction at $120{ }^{\circ} \mathrm{C}$ gave the same yield as at $100{ }^{\circ} \mathrm{C}(\mathrm{Ta}-$ ble 1, Entries 2, 3). The loading amount of DMTCC also has a great influence on the outcome of the reaction. By working with 1.5 equiv. of DMTCC, the reaction could be completed within $0.8 \mathrm{~h}$ and the yield of $\mathbf{2 a}$ increased to $87 \%$ (Table 1, Entry 4). When the amount of DMTCC was raised to 2.0 equiv., a higher yield was obtained (Table 1, Entry 5). However, a further increase in the amount of DMTCC to 3.0 equiv. could not improve the yield (Table 1, Entry 6).

With the optimal reaction conditions in hand (Table 1, Entry 5), the generality of this DMTCC-mediated deoxygenation reaction was subsequently investigated, and some of the results are summarized in Table 2. Initially, a gramscale synthesis was carried out under optimal conditions, in
Table 1 Optimization of reaction conditions ${ }^{a}$

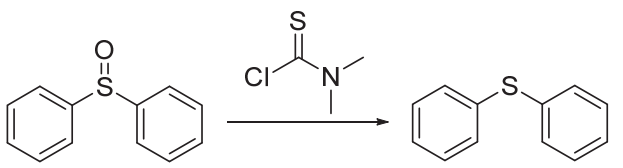

$1 \mathrm{a}$

$2 a$

\begin{tabular}{ccccc}
\hline Entry & DMTCC/equiv. & $T /{ }^{\circ} \mathrm{C}$ & Time/h & Yield $^{b} \%$ \\
\hline 1 & 1.0 & 100 & 2.0 & $81^{c}$ \\
2 & 1.0 & 80 & 2.0 & $70^{d}$ \\
3 & 1.0 & 120 & 2.0 & $81^{e}$ \\
4 & 1.5 & 100 & 0.8 & 87 \\
5 & 2.0 & 100 & 0.5 & 92 \\
6 & 3.0 & 100 & 0.5 & 92 \\
\hline
\end{tabular}

${ }^{a}$ Reactions conducted with $1 \mathrm{mmol}$ of diphenyl sulfoxide under air atmosphere. ${ }^{b}$ Isolated yields. ${ }^{c} 14 \%$ of 1 a was recovered. ${ }^{d} 26 \%$ of 1 a was recovered.

${ }^{e} 12 \%$ of 1 a was recovered.

which $90 \%$ yield of 2 a could be obtained from $10 \mathrm{mmol}$ 1a, indicating that the reaction can be scaled up easily. Then, the reactivity of substituted diphenyl sulfoxide derivatives was studied. When electron-donating groups, such as methoxy and methyl groups, are attached at the 4,4'-positions of the benzene rings, diary thioethers $\mathbf{2} \mathbf{b}$ and 2c could be obtained in $89 \%$ and $85 \%$ yields, respectively. However, only a complicated reaction mixture was formed from 4,4'-diaminodiphenyl sulfoxide, suggesting that a free amino group is incompatible in the current transformation. With regard to electron-withdrawing groups substituted diaryl sulfoxides, chloro and nitro groups attached at the 4,4'-positions of the benzene rings could be tolerated well, affording the target products 2d and 2e in $87 \%$ and $60 \%$ yields, respectively. Notably, 2,2',5,5'-tetramethyl substituted diphenyl sulfoxide could also be employed to obtain 2f in $86 \%$ yield, regardless of the large steric hindrance. Moreover, the reaction could be extended to heteroaryl sulfoxide 3 -( $p$-tolylsulfinyl)- $H$-indole, leading to the corresponding heteroaryl thioether $\mathbf{2 g}$ in $73 \%$ yield. Diben$\mathrm{zo}[b, d]$ thiophene 5-oxide was also amenable to this reaction, giving dibenzo[b,d]thiophene $\mathbf{2 h}$ in $90 \%$ yield. Besides diaryl sulfoxides, the reaction is also applicable for aryl alkyl sulfoxides and dialkyl sulfoxides, affording the corresponding thioethers $\mathbf{2} \mathbf{i} \sim \mathbf{2 0}$ in $81 \% \sim 88 \%$ yields. It has been reported that treatment of alkyl sulfoxides with acid chlorides always lead to the formation of $\alpha$-chloro thioethers. ${ }^{[19]}$ However, no chlorinated thioethers were observed in the present work. More importantly, the benzyl, nitro, triple bond, ester, and ketone groups on the substrates remained intact under the reaction conditions $(\mathbf{2} \mathbf{j} \sim$ 2o), which further exhibits the excellent chemoselectivity of this protocol. In contrast to the facile reaction of sulfoxides, no reaction was observed when diphenyl sulfone was subjected to DMTCC even at higher temperatures. This result suggested that the polarized nature of sulfoxides is critical for the DMTCC-mediated deoxygenation reaction.

It should be mentioned that during the course of the gram-scale synthesis of $\mathbf{2 a}$, a light-yellow crystal was ob- 
served after the completion of the reaction. The crystal was identified as elemental sulfur by combustion and melting point test. To gain more insight into the mechanism of this deoxygenation reaction, the crude reaction mixture of diphenyl sulfoxide 1a was investigated by means of ${ }^{1} \mathrm{H}$ NMR and ${ }^{13} \mathrm{C}$ NMR spectroscopies. As a result, diphenyl thioether 2a, DMTCC, and an unexpected product dimethylcarbamoyl chloride were determined by comparison of their NMR spectra (see the supporting information) with those reported in the literature. ${ }^{[20]}$ Obviously, DMTCC was transformed into dimethylcarbamoyl chloride during the deoxygenation process. Moreover, the intensity of the ${ }^{1} \mathrm{H}$ NMR spectroscopic signals of dimethylcarbamoyl chloride is as strong as that of $\mathbf{2 a}$, indicating the reaction of sulfoxides with DMTCC is essentially an equimolar reaction. These results provided direct evidences of the fact that sulfoxide is essentially reduced by the S atom of DMTCC.

Although the detailed mechanism was unclear, on the basis of the results obtained above together with some literature reports, plausible reaction pathways were proposed in Scheme 1. Initially, sulfoxide $\mathbf{1}$ undergoes an addition-cyclization reaction with DMTCC to form the fourmembered ring intermediate $\mathbf{B}$, which further degrades into dimethylcarbamoyl chloride and thiosulfoxide intermediate
C. ${ }^{[14,16,21]}$ With the release of elemental sulfur, $\mathbf{C}$ is finally transformed into thioether 2. $^{[6]}$

\section{Conclusions}

In summary, a facile and efficient deoxygenation of sulfoxides is developed by the reaction of sulfoxides with dimethylthiocarbamoyl chloride at $100{ }^{\circ} \mathrm{C}$ without any additional catalyst and solvent. Notably, dimethylthiocarbamoyl chloride functionalizes as an odorless thionating reagent in the reaction and can be conveniently and safely handled in typical laboratory operations. We believe that the ease of operation and the good tolerance of sensitive functional groups will make this procedure very attractive for reduction of sulfoxides to thioethers. Further studies on the scope and mechanism of the reaction are underway in our laboratory.

\section{Experimental section}

\subsection{General}

All other reagents were purchased from commercial sources and used without treatment, unless otherwise indicated. Reactions were routinely carried out under an atmosphere with magnetic stirring and monitored by thinlayer

Table 2 Scope of sulfoxides $\mathbf{1}^{a}$
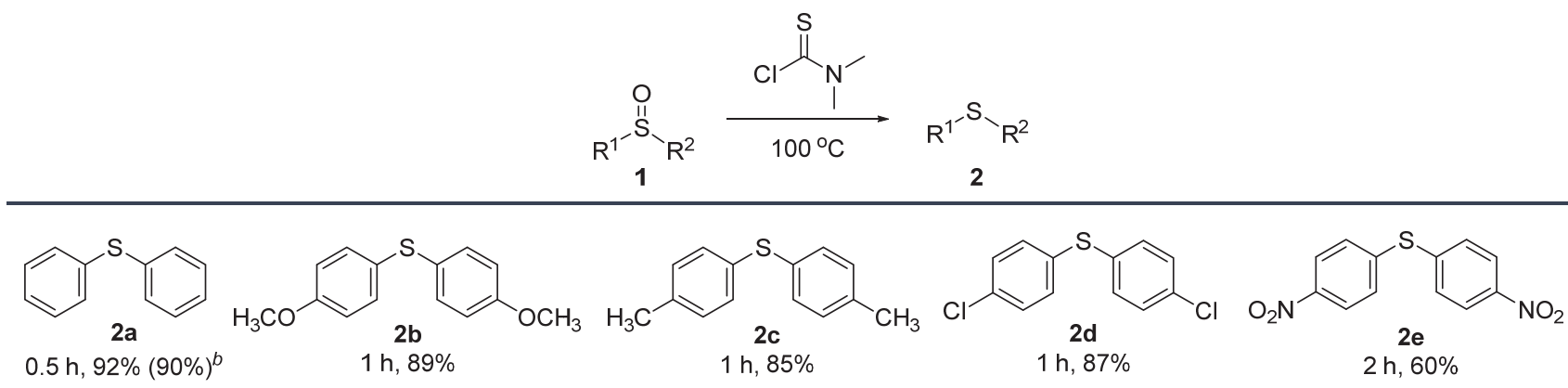<smiles>CCCCCCC</smiles>

$2 \mathrm{~h}, 86 \%$<smiles>Cc1ccc(SCc2ccc([N+](=O)[O-])cc2)cc1</smiles>

$2 \mathrm{~h}, 88 \%$

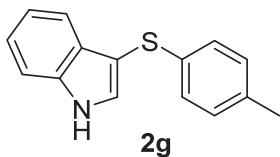

$1 \mathrm{~h}, 73 \%$

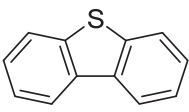

$2 \mathrm{~h}$ 0.5 h, $90 \%$<smiles>CSc1ccc(C)cc1</smiles>

2i $1 \mathrm{~h}, 81 \%$<smiles>Cc1ccc(SCc2ccccc2)cc1</smiles>

2 h, $82 \%$<smiles>c1ccc(CSCc2ccccc2)cc1</smiles>

21

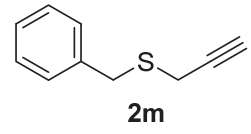

2 h, $83 \%$<smiles>CCOC(=O)CSCc1ccccc1</smiles>

$2 n$

2 h, $88 \%$

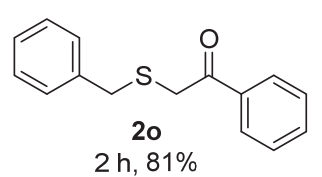

${ }^{a}$ Unless otherwise noted, all the reactions were conducted with sulfoxide $1(1.0 \mathrm{mmol})$ and dimethylthiocarbamoyl chloride $(2.0 \mathrm{mmol})$ at $100{ }^{\circ} \mathrm{C}$ under air atmosphere for the indicated time, and the yields were calculated based on the weight of the isolated products. ${ }^{b} 10$ mmol of $\mathbf{1 a}$ was used in the reaction.

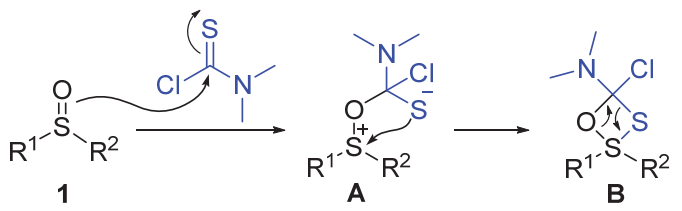<smiles>CCCCCN(C)C(=O)Cl</smiles>

$\mathrm{R}_{\mathrm{C}}^{\mathrm{II}_{\mathrm{S}}^{\mathrm{S}} \mathrm{R}^{2}} \underbrace{}_{\frac{1}{8} \mathrm{~S}_{8}} \mathrm{R}_{2}^{1^{-S} \backslash_{\mathrm{R}^{2}}}$

Scheme 1 Proposed reaction mechanism 
chromatography (TLC) using silica gel F254 plates. Products were purified by column chromatography over $200 \sim$ 300 mesh silica gel under a positive pressure of air. ${ }^{1} \mathrm{H}$ NMR and ${ }^{13} \mathrm{C}$ NMR spectra were recorded at $25{ }^{\circ} \mathrm{C}$ at 300 $\mathrm{MHz}$ (or $600 \mathrm{MHz}$ ) and $75 \mathrm{MHz}$, respectively, using tetramethyl silane (TMS) as an internal standard. Melting points were determined with a TECH X-4 micro-melting point apparatus and are reported as uncorrected. All of the substrates, $\mathbf{1 a} \sim \mathbf{1 d},{ }^{[22]} \mathbf{1 e},^{[23]} \mathbf{1 f},{ }^{[22]} \mathbf{1 g},{ }^{[23-24]} \mathbf{1 h},{ }^{[25]} \mathbf{1 i},,^{[26]}$ $\mathbf{1 j} \sim \mathbf{1} \mathbf{k},{ }^{[27]} \mathbf{1 1},{ }^{[28]} \mathbf{1} \mathbf{m},{ }^{[29]} \mathbf{1} \mathbf{n}^{[30]}$ and $\mathbf{1 o},{ }^{[31]}$ are known compounds, they were synthesized according to the reported procedures, and their analytical data are in good agreement with those in the literatures.

\subsection{General procedure for the deoxygenation of sulfoxides}

Deoxygenation of diphenyl sulfoxide $\mathbf{1 a}$ is described as an example: a mixture of diphenyl sulfoxide $(0.202 \mathrm{~g}, 1$ $\mathrm{mmol})$ and dimethylthiocarbamoyl chloride $(0.247 \mathrm{~g}, 2$ mmol) in a sealed tube was heated to $100{ }^{\circ} \mathrm{C}$ and stirred for $0.5 \mathrm{~h}$. After 1a was consumed as monitored by TLC, the resulting mixture was cooled down to room temperature, then poured into saturated aqueous $\mathrm{Na}_{2} \mathrm{CO}_{3}(30 \mathrm{~mL})$ and extracted with dichloromethane $(20 \mathrm{~mL} \times 3)$. The combined organic phase was washed with water $(20 \mathrm{~mL} \times 3)$, dried over $\mathrm{Na}_{2} \mathrm{SO}_{4}$, filtered and concentrated in vacuo. The crude product was purified by flash column chromatography (silica gel, petroleum ether) to give diphenyl thioether $\mathbf{2 a}$ in $92 \%$ yield.

Gram-scale synthesis of diphenyl thioether $\mathbf{2 a}$ : a mixture of diphenyl sulfoxide $(2.022 \mathrm{~g}, 10 \mathrm{mmol})$ and dimethylthiocarbamoyl chloride ( $2.472 \mathrm{~g}, 20 \mathrm{mmol}$, ) in a sealed tube was heated to $100{ }^{\circ} \mathrm{C}$ and stirred for $0.5 \mathrm{~h}$. After 1a was consumed (monitored by TLC), the resulting mixture was cooled down to room temperature. The precipitated elemental sulfur was filtered out and the filtrate was poured into saturated aqueous $\mathrm{Na}_{2} \mathrm{CO}_{3}(50 \mathrm{~mL})$ and extracted with dichloromethane $(20 \mathrm{~mL} \times 3)$. The combined organic phase was washed with water $(20 \mathrm{~mL} \times 3)$, dried over $\mathrm{Na}_{2} \mathrm{SO}_{4}$, filtered and concentrated in vacuo. The crude product was purified by flash column chromatography (silica gel, petroleum ether) to give diphenyl thioether $\mathbf{2 a}$ in $90 \%$ yield.

All of the products $\mathbf{2 a} \sim \mathbf{2 0}$ are known compounds, their analytical data are in good agreement with those in the literatures.

Diphenylsulfane (2a): ${ }^{[9 a]}$ Pale yellow oil. ${ }^{1} \mathrm{H}$ NMR (600 MHz, DMSO- $\left.d_{6}\right) \delta: 7.30(\mathrm{t}, J=7.2 \mathrm{~Hz}, 4 \mathrm{H}), 7.33 \sim 7.38$ $(\mathrm{m}, 6 \mathrm{H}) ;{ }^{13} \mathrm{C}$ NMR $\left(75 \mathrm{MHz}\right.$, DMSO- $\left.d_{6}\right) \delta: 127.7,129.8$, 130.9, 135.0.

Bis(4-methoxyphenyl)sulfane (2b): Pale yellow solid, m.p. $43 \sim 44{ }^{\circ} \mathrm{C}$ (lit. $\left.{ }^{[9 a]} 44 \sim 45{ }^{\circ} \mathrm{C}\right) ;{ }^{1} \mathrm{H}$ NMR $(300 \mathrm{MHz}$, $\left.\mathrm{CDCl}_{3}\right) \delta: 3.78(\mathrm{~s}, 6 \mathrm{H}), 6.83(\mathrm{~d}, J=9 \mathrm{~Hz}, 4 \mathrm{H}), 7.27(\mathrm{~d}, J=$ $9 \mathrm{~Hz}, 4 \mathrm{H}) ;{ }^{13} \mathrm{C} \mathrm{NMR}\left(75 \mathrm{MHz}, \mathrm{CDCl}_{3}\right) \delta: 55.2,114.6$, 127.3, 132.6, 158.8.

Di-p-tolylsulfane (2c): White solid, m.p. $56 \sim 57{ }^{\circ} \mathrm{C}$ (lit. ${ }^{\text {[9] }}$ 56 $\left.57{ }^{\circ} \mathrm{C}\right) ;{ }^{1} \mathrm{H}$ NMR $\left(300 \mathrm{MHz}, \mathrm{CDCl}_{3}\right) \delta: 2.32$ (s, $6 \mathrm{H}), 7.10(\mathrm{~d}, J=7.8 \mathrm{~Hz}, 4 \mathrm{H}), 7.23(\mathrm{~d}, J=7.8 \mathrm{~Hz}, 4 \mathrm{H}) ;{ }^{13} \mathrm{C}$
NMR (75 MHz, $\left.\mathrm{CDCl}_{3}\right) \delta: 21.0,129.8,131.0,132.6$, 136.8 .

Bis(4-chlorophenyl)sulfane (2d): White solid, m.p. 88 $89{ }^{\circ} \mathrm{C}$ (lit. $\left.{ }^{[9 \mathrm{a}]} 87 \sim 88{ }^{\circ} \mathrm{C}\right) ;{ }^{1} \mathrm{H} \mathrm{NMR}\left(300 \mathrm{MHz}, \mathrm{CDCl}_{3}\right) \delta$ : $7.23 \sim 7.30(\mathrm{~m}, 8 \mathrm{H}) ;{ }^{13} \mathrm{C}$ NMR $\left(75 \mathrm{MHz}, \mathrm{CDCl}_{3}\right) \delta: 129.4$, 132.2, 133.4, 133.9 .

Bis(4-nitrophenyl)sulfane (2e): Yellow solid, m.p. $163 \sim 164{ }^{\circ} \mathrm{C}$ (lit. $\left.{ }^{[23]} 161 \sim 164{ }^{\circ} \mathrm{C}\right) ;{ }^{1} \mathrm{H}$ NMR (300 MHz, $\left.\mathrm{CDCl}_{3}\right) \delta: 7.50(\mathrm{~d}, J=8.6 \mathrm{~Hz}, 4 \mathrm{H}), 8.22(\mathrm{~d}, J=8.6 \mathrm{~Hz}$, $4 \mathrm{H}) ;{ }^{13} \mathrm{C}$ NMR (75 MHz, $\left.\mathrm{CDCl}_{3}\right) \delta: 124.6,131.1,142.6$, 147.1 .

Bis(2,5-dimethylphenyl)sulfane (2f): $:{ }^{[32]}$ Colorless oil; ${ }^{1} \mathrm{H}$ NMR $\left(300 \mathrm{MHz}, \mathrm{CDCl}_{3}\right) \delta: 2.22(\mathrm{~s}, 6 \mathrm{H}), 2.33(\mathrm{~s}, 6 \mathrm{H}), 6.88$ (s, 2H), 6.97 (d, $J=7.8 \mathrm{~Hz}, 2 \mathrm{H}), 7.11(\mathrm{~d}, J=7.8 \mathrm{~Hz}, 2 \mathrm{H})$; ${ }^{13} \mathrm{C}$ NMR $\left(75 \mathrm{MHz}, \mathrm{CDCl}_{3}\right) \delta: 19.9,20.9,127.8,130.2$, 131.5, 133.9, 135.6, 136.2.

3-( $p$-Tolylthio)-1H-indole (2g): White solid, m.p. 124 $126{ }^{\circ} \mathrm{C}$ (lit. $\left.{ }^{[24]} 128 \sim 130{ }^{\circ} \mathrm{C}\right) ;{ }^{1} \mathrm{H}$ NMR (300 MHz, $\left.\mathrm{CDCl}_{3}\right) \delta: 2.24(\mathrm{~s}, 3 \mathrm{H}), 6.97(\mathrm{~d}, J=8.1 \mathrm{~Hz}, 2 \mathrm{H}), 7.02(\mathrm{~d}$, $J=8.1 \mathrm{~Hz}, 2 \mathrm{H}), 7.15(\mathrm{td}, J=7.5,1.0 \mathrm{~Hz}, 1 \mathrm{H}), 7.22 \sim 7.25$ $(\mathrm{m}, 1 \mathrm{H}), 7.41(\mathrm{~d}, J=8.1 \mathrm{~Hz}, 1 \mathrm{H}), 7.44(\mathrm{~s}, 1 \mathrm{H}), 7.61(\mathrm{~d}, J=$ 7.6, $1 \mathrm{H}), 8.31(\mathrm{~s}, 1 \mathrm{H}) ;{ }^{13} \mathrm{C} \mathrm{NMR}\left(75 \mathrm{MHz}, \mathrm{CDCl}_{3}\right) \delta: 20.8$, $102.9,111.5,119.5,120.7,122.8,126.1,128.9,129.4$, $130.5,134.6,135.3,136.3$.

Dibenzo[ $b, d]$ thiophene (2h): White solid, m.p. 98 $100{ }^{\circ} \mathrm{C}$ (lit. $\left.{ }^{[3]} 99 \sim 100{ }^{\circ} \mathrm{C}\right)$; ${ }^{1} \mathrm{H}$ NMR $\left(300 \mathrm{MHz}, \mathrm{CDCl}_{3}\right.$ ) $\delta: 7.42 \sim 7.49(\mathrm{~m}, 4 \mathrm{H}), 7.82 \sim 7.89(\mathrm{~m}, 2 \mathrm{H}), 8.14 \sim 8.17$ $(\mathrm{m}, 2 \mathrm{H}) ;{ }^{13} \mathrm{C} \mathrm{NMR}\left(75 \mathrm{MHz}, \mathrm{CDCl}_{3}\right) \delta: 121.5,122.7$, 124.2, 126.6, 135.4, 139.3.

Methyl( $p$-tolyl)sulfane (2i): ${ }^{[10 a]}$ Pale yellow oil. ${ }^{1} \mathrm{H}$ NMR $\left(300 \mathrm{MHz}, \mathrm{CDCl}_{3}\right) \delta: 2.31(\mathrm{~s}, 3 \mathrm{H}), 2.47(\mathrm{~s}, 3 \mathrm{H}), 7.10(\mathrm{~d}$, $J=8.1,2 \mathrm{H}), 7.19(\mathrm{~d}, J=8.1 \mathrm{~Hz}, 2 \mathrm{H}) ;{ }^{13} \mathrm{C} \mathrm{NMR}(75 \mathrm{MHz}$, $\left.\mathrm{CDCl}_{3}\right) \delta: 16.7,20.9,127.2,129.6,134.3,135.1$.

Benzyl(p-tolyl)sulfane (2j): White solid, m.p. $44 \sim$ $45{ }^{\circ} \mathrm{C}$ (lit. $\left.{ }^{[5 \mathrm{a}]} 44 \sim 46{ }^{\circ} \mathrm{C}\right) ;{ }^{1} \mathrm{H}$ NMR $\left(600 \mathrm{MHz}, \mathrm{CDCl}_{3}\right) \delta$ : $2.30(\mathrm{~s}, 3 \mathrm{H}), 4.06(\mathrm{~s}, 2 \mathrm{H}), 7.06(\mathrm{~d}, J=7.2 \mathrm{~Hz}, 2 \mathrm{H}), 7.20 \sim$ $7.22(\mathrm{~m}, 3 \mathrm{H}), 7.26(\mathrm{~s}, 4 \mathrm{H}) ;{ }^{13} \mathrm{C} \mathrm{NMR}\left(75 \mathrm{MHz} \mathrm{CDCl}_{3}\right) \delta$ : 21.0, 39.6, 126.9, 128.3, 128.7, 129.5, 130.5, 132.4, 136.4, 137.6 .

(4-Nitrobenzyl)( $p$-tolyl)sulfane (2k): White solid, m.p. $102 \sim 103{ }^{\circ} \mathrm{C}$ (lit. ${ }^{[7 \mathrm{a}]} 100 \sim 101{ }^{\circ} \mathrm{C}$ ); ${ }^{1} \mathrm{H}$ NMR $(300 \mathrm{MHz}$, CDCl3) $\delta: 2.31(\mathrm{~s}, 3 \mathrm{H}), 4.07(\mathrm{~s}, 2 \mathrm{H}), 7.06(\mathrm{~d}, J=8.1 \mathrm{~Hz}$, 2H), $7.17(\mathrm{~d}, J=8.1 \mathrm{~Hz}, 2 \mathrm{H}), 7.34(\mathrm{~d}, J=8.7 \mathrm{~Hz}, 2 \mathrm{H}), 8.10$ $(\mathrm{dt}, J=8.7,2.1 \mathrm{~Hz}, 2 \mathrm{H}) ;{ }^{13} \mathrm{C} \mathrm{NMR}\left(75 \mathrm{MHz}, \mathrm{CDCl}_{3}\right) \delta$ : 21.1, 39.6, 123.6, 129.5, 129.8, 130.5, 131.8, 137.6, 145.8.

Dibenzylsulfane (2l): White solid, m.p. $49 \sim 50{ }^{\circ} \mathrm{C}$ (lit. $\left.{ }^{\text {9a] }} 48 \sim 49{ }^{\circ} \mathrm{C}\right)$; ${ }^{1} \mathrm{H}$ NMR $\left(300 \mathrm{MHz}, \mathrm{CDCl}_{3}\right) \delta: 3.59$ (s, 4H), $7.21 \sim 7.34(\mathrm{~m}, 10 \mathrm{H}) ;{ }^{13} \mathrm{C} \mathrm{NMR}\left(75 \mathrm{MHz}, \mathrm{CDCl}_{3}\right) \delta$ : 35.4, 126.8, 128.3, 128.9, 138.0 .

Benzyl(prop-2-yn-1-yl)sulfane (2m): ${ }^{[34]}$ Colorless oil. ${ }^{1} \mathrm{H}$ NMR (300 MHz, $\left.\mathrm{CDCl}_{3}\right) \delta: 2.29(\mathrm{~s}, 1 \mathrm{H}), 3.07$ (d, $J=$ $2.4 \mathrm{~Hz}, 2 \mathrm{H}), 3.87(\mathrm{~s}, 2 \mathrm{H}), 7.25 \sim 7.34(\mathrm{~m}, 5 \mathrm{H}) ;{ }^{13} \mathrm{C} \mathrm{NMR}$ $\left(75 \mathrm{MHz}, \mathrm{CDCl}_{3}\right) \delta: 18.2,35.1,71.2,79.7,127.1,128.4$, 128.9, 137.3.

Ethyl 2-(benzylthio)acetate (2n): White solid, m.p. 58 $60{ }^{\circ} \mathrm{C}$ (lit. ${ }^{[30]}$ colorless oil); ${ }^{1} \mathrm{H}$ NMR $\left(300 \mathrm{MHz}, \mathrm{CDCl}_{3}\right.$ ) $\delta$ : $1.29(\mathrm{t}, J=7.1 \mathrm{~Hz}, 3 \mathrm{H}), 3.06(\mathrm{~s}, 2 \mathrm{H}), 3.83(\mathrm{~s}, 2 \mathrm{H}), 4.17$ 
$(\mathrm{q}, J=7.1 \mathrm{~Hz}, 2 \mathrm{H}), 7.22 \sim 7.35(\mathrm{~m}, 5 \mathrm{H}) ;{ }^{13} \mathrm{C}$ NMR $(75$ $\left.\mathrm{MHz}, \mathrm{CDCl}_{3}\right) \delta: 13.9,31.8,35.9,60.9,126.9,128.2,128.8$, $136.9,170.0$.

2-(Benzylthio)-1-phenylethanone (2o): White solid, m.p. $87 \sim 88{ }^{\circ} \mathrm{C}$ (lit. $\left.{ }^{[35]} 87 \sim 89{ }^{\circ} \mathrm{C}\right)$; ${ }^{1} \mathrm{H}$ NMR $(300 \mathrm{MHz}$, $\left.\mathrm{CDCl}_{3}\right) \delta: 3.67(\mathrm{~s}, 2 \mathrm{H}), 3.76(\mathrm{~s}, 2 \mathrm{H}), 7.22 \sim 7.36(\mathrm{~m}, 5 \mathrm{H})$, 7.45 (t, $J=7.6 \mathrm{~Hz}, 2 \mathrm{H}), 7.57$ (t, $J=7.6 \mathrm{~Hz}, 1 \mathrm{H}), 7.93$ (d, $J=8.1 \mathrm{~Hz}, 2 \mathrm{H}) ;{ }^{13} \mathrm{C} \mathrm{NMR}\left(75 \mathrm{MHz}, \mathrm{CDCl}_{3}\right) \delta: 35.7,35.9$, $127.1,128.4,128.5,128.6,129.1,133.2,135.2,137.2$, 194.2.

Supporting Information Copies of ${ }^{1} \mathrm{H}$ NMR and ${ }^{13} \mathrm{C}$ NMR spectra for compound $\mathbf{2}$ and the crude reaction mixture of 1a. Photograph for the deposition of elemental sulfur in the vessel after the completion of the scale-up reaction of 1a. The Supporting Information is available free of charge via the Internet at http://sioc-journal.cn/.

\section{References}

[1] Li, W.; Chen, X.; Zheng, T.; Zou, Q.; Chen, W. Chin. J. Org. Chem. 2019, 39, 2443 (in Chinese).

(李伟林, 陈炫颖, 郑天骄, 邹祺, 陈文博, 有机化学, 2019, 39, 2443.)

[2] (a) Oh, K.; Knabe, W. E. Tetrahedron 2009, 65, 2966.

(b) Yoo, B. W.; Yu, B. R.; Yoon, C. M. J. Sulfur Chem. 2015, 36, 358.

(c) Tang, W.-M.; Li, J.-S.; Chan, T. H. Acta Chim. Sinica 1987, 45, 472 (in Chinese). (唐文明, 李纪生, 陈德恒, 化学学报, 1987, 45, 472.)

[3] (a) Yakabe, S.; Hirano, M.; Morimoto, T. Synth. Commun. 2011, 41, 2251.

(b) Yoon, N. M.; Gyoung, Y. S. J. Org. Chem. 1985, 50, 2443.

(c) Brown, H. C.; Weissman, P. M.; Yoon, N. M. J. Am. Chem. Soc. 1966, $88,1458$.

[4] (a) Ma, R.; Liu, A.-H.; Huang, C.-B.; Li, X.-D.; He, L.-N. Green Chem. 2013, 15, 1274.

(b) Lee, G. H.; Choi, E. B.; Lee, E.; Pak, C. S. Tetrahedron Lett. 1994, 35, 2195.

[5] (a) Zhao, X.; Zheng, X.; Yang, B.; Sheng, J.; Lu, K. Org. Biomol. Chem. 2018, 16, 1200.

(b) Denis, J. N.; Krief, A. Tetrahedron Lett. 1979, 20, 3995

(c) Jie, Z.; Rammoorty, V.; Fischer, B. J. Org. Chem. 2002, 67, 711.

[6] (a) Bartsch, H.; Erker, T. Tetrahedron Lett. 1992, 33, 199.

(b) Baechler, R. D.; Daley, S. K. Tetrahedron Lett. 1978, 19, 101.

(c) Still, I. W. J.; Reed, J. N.; Turnbull, K. Tetrahedron Lett. 1979, $20,1481$.

[7] (a) Bahrami, K.; Khodaei, M. M.; Karimi, A. Synthesis 2008, 2543. (b) Abbasi, M.; Mohammadizadeh, M. R.; Moradi, Z. Bull. Chem. Soc. Jpn. 2016, 89, 405.

(c) Pourmousavi, S. A.; Salehi, P. Phosphorus, Sulfur Silicon Relat. Elem. 2010, 185, 803 .

[8] (a) Mitsudome, T.; Takahashi, Y.; Mizugaki, T.; Jitsukawa, K.; Kaneda, K. Angew. Chem., Int. Ed. 2014, 53, 8348.

(b) Uematsu, T.; Ogasawara, Y.; Suzuki, K.; Yamaguchi, K.; Mizuno, N. Catal. Sci. Technol. 2017, 7, 1912.

[9] (a) Takahashi, F.; Nogi, K.; Yorimitsu, H. Eur. J. Org. Chem. 2020, 2020, 3009 .

(b) Guindon, Y.; Atkinson, J. G.; Morton, H. E. J. Org. Chem. 1984, 49, 4539 .

(c) Fernandes, A. C.; Romão, C. C. Tetrahedron Lett. 2007, 48,
9176.

[10] (a) Gevorgyan, A.; Mkrtchyan, S.; Grigoryan, T.; Iaroshenko, V. O. Org. Chem. Front. 2017, 4, 2437.

(b) Cabrita, I.; Sousa, S. C. A.; Fernandes, A. C. Tetrahedron Lett. 2010, 51, 6132.

(c) Ding, F.; Jiang, Y.; Gan, S.; Bao, R. L.-Y.; Lin, K.; Shi, L. Eur. J. Org. Chem. 2017, 3427.

[11] (a) Jiang, L.; Yan, Q.; Wang, R.; Ding, T.; Yi, W.; Zhang, W. Chem.Eur. J. 2018, 24, 18749.

(b) Numata, T.; Ikura, K.; Shimano, Y.; Oae, S. Org. Prep. Proc. Int. 1976, 8, 119.

[12] Babudri, F.; Fiandanese, V.; Marchese, G.; Punzi, A. Synlett 1994, 719.

[13] Petrovski, Ž.; Martins, B. M. R.; Afonso, C. A. M. Tetrahedron Lett. 2010, 51, 3356

[14] Li, W.; Zhao, Y.; Mai, S.; Song, Q. Org. Lett. 2018, 20, 1162.

[15] Kapanda, C. N.; Muccioli, G. G.; Labar, G.; Poupaert, J. H.; Lambert, D. M. J. Med. Chem. 2009, 52, 7310.

[16] Broese, T.; Roesel. A. F.; Prudlik, A.; Francke, R. Org. Lett. 2018 , 20,7483 .

[17] Huang, P.; Zhang, R.; Liang, Y.; Dong, D. Org. Biomol. Chem. 2012, 10, 1639 .

[18] (a) Yang, L.; Wan, J.-P. Green Chem. 2020, 22, 3074

(b) Yu, Q.; Zhang, Y.; Wan, J.-P. Green Chem. 2019, 21, 3436.

(c) Kong, Q.; Li, X.; Xu, H.; Fu, Y. Chin. J. Org. Chem. 2020, 40, 2062 (in Chinese).

(孔庆山，李兴龙，许华建，傅尧，有机化学, 2020, 40, 2062.)

(d) Shen, T.; Ouyang, B.; Zhou, S.; Qian, C.; Chen, X. Chin. J. Org. Chem. 2019, 39, 873 (in Chinese).

(沈涛, 欧阳博, 周少东, 钱超, 陈新志, 有机化学, 2019, 39, 873.)

[19] Jiang, Y.; Kim, K. T.; Jeon, H. B. J. Org. Chem. 2013, 78, 6328.

[20] Rabiller, C.; Renou, J. P.; Martin, G. J. J. Chem. Soc., Perkin Trans. $21977,536$.

[21] Kamijo, H.; Takido, T.; Nakazawa, T.; Itabashi, K.; Seno, M. Phosphorus, Sulfur Silicon Relat. Elem. 1993, 82, 207.

[22] Olah, G. A.; Marinez, E. R.; Prakash, G. K. S. Synlett 1999, 1397.

[23] Chun, J.-H.; Morse, C. L.; Chin, F. T.; Pike, V. W. Chem. Commun. 2013, 49, 2151.

[24] He, Y.; Jiang, J.; Bao, W.; Deng, W.; Xiang, J. Tetrahedron Lett. 2017, 58, 4583.

[25] Li, X.; Sun, Y.; Huang, X.; Zhang, L.; Kong, L.; Peng, B. Org. Lett. 2017, 19,838.

[26] Hendriks, C. M. M.; Lamers, P.; Engel, J.; Bolm, C. Adv. Synth. Catal. 2013, 355, 3363.

[27] Liu, Q.; Zhao, X.; Xu, F.; Li, G. Tetrahedron Lett. 2020, 61, 151492

[28] Xie, Y.; Li, Y.; Zhou, S.; Zhou, S. Zhang, Y.; Chen, M.; Li, Z. Synlett 2018, 29, 340 .

[29] Skattebøl, L.; Boulette, B.; Solomon, S. J. Org. Chem. 1968, 32, 548.

[30] Wang, X.; Xue, Z.; Ma, Y.; Yang, F. J. Chem. Res. 2014, 38, 493.

[31] Chang, M.-Y.; Cheng, Y.-C.; Chan, C.-K. Tetrahedron 2016, 72, 4068.

[32] Fernández-Salas, J. A.; Pulis, A. P.; Procter, D. J. Chem. Commun. 2016, 52,12364

[33] Prakash, G. K. S.; Weber, C.; Chacko, S.; Olah, G. A. Org. Lett. 2007, 9, 1863.

[34] Kaschula, C. H.; Hunter, R.; Stellenboom, N.; Caira, M. R.; Winks, S.; Ogunleye, T.; Richards, P.; Cotton, J.; Zilbeyaz, K.; Wang, Y.; Siyo, V.; Ngarande, E.; Parker, M. I. Eur. J. Med. Chem. 2012, 50, 236.

[35] Xu, X.-B.; Lin, Z.-H.; Liu, Y.; Guo, J.; He, Y. Org. Biomol. Chem. 2017, 15, 2716.

(Lu, Y.) 